\title{
I Chronicles 1-9. (The Anchor Bible Vol. 12)
}

By GN Knoppers

New York: Doubleday

2003

Pp. i-xxii $+1-514$

Price: US $\$ 49.50$

\section{Chronicles 10-29. (The Anchor Bible Vol. 12A)}

\author{
By GN Knoppers
}

New York: Doubleday

2004

Pp. i-xxii

Price: US $\$ 49.50$

Reviewed by:

Dr Louis Jonker

Department of Old and New Testament

Stellenbosch University

Gary Knoppers (Penn State University) has established himself over many years and

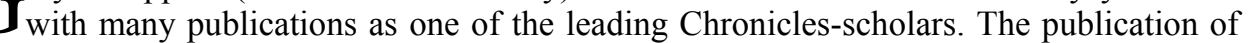
the first two volumes of his Chronicles commentary in The Anchor Bible series is therefore a culmination of respected work done over decades.

Knoppers starts his commentary (in Vol. 12) with a new translation of the whole 1 Chronicles. His translation reflects the critical decisions he has made in his exegesis and which is argued in the body of his commentary. After the translation follows an excellent introduction to the important scholarly issues which presently dominate Chronicles scholarship. This introduction is not only a very good overview of different opinions that have been expressed in past scholarship, but is also a very clear systematization of these opinions. Especially in the section titled "The Chronicler's use of earlier biblical books" Knoppers makes a valuable contribution with his warning against too simple and hasty conclusions. In this section, which could certainly be described as the core explanation of his own method, cautions scholars not to work too simplistically when they try to find explanations for the differences between Chronicles and and its biblical Vorlagen. Often 
these differences are attributed to the unique ideological perspective of the Chronicler. However, Knoppers points out that these differences can in many cases rather be explained with reference to another (normally older) version of the Vorlage. He therefore states: "Since Chronicles not only quotes but also rephrases, alludes to, and reinterprets older texts, textual criticism is of great consequence for understanding both the Chronicler's method and his purpose. ... But given the multiplicity of textual traditions manifest in the history of any given biblical book, how does one know when the writer is consciously deviating from the text before him (his Vorlage) and when he is faithfully quoting his source? ... The textual criticism of Chronicles involves, therefore, not only a comparative study of the various versions of Chronicles, but also a careful study of the various versions to the biblical books from which the author quotes" (p. 69). In this respect Knoppers shows himself to be a very able scholar.

In another section of the Introduction Knoppers addresses the question whether Chronicles could be described as "a rewritten Bible". With reference to the definitions other scholars have attached to this depiction, and showing due caution not to use the word "Bible" anachronistically here, Knoppers explains what he understands this indication means: "In spite of the differences among critics about what qualifies as a rewritten-Bible text, some generalizations are possible. Such works take as a point of departure an earlier biblical book or collection of books. They select from, interpret, comment on, and expand portions of a particular biblical book (or group of books), addressing obscurities, contradictions, and other perceived problems with the source text. Rewritten texts normally emulate the form of the source text and follow it sequentially. The major intention of such works seems to be to provide a coherent interpretive reading of the biblical text. The added comments, interpolated into the sources, are often of a moral, theological, or didactic type. The authors of rewritten biblical texts fuse their own additions, clarifications, and expositions with the base text. They normally follow the narration of events found in their biblical source and do not employ citation formulas to distinguish their own material from that found within the source. The authors may presuppose some familiarity on the part of the readers with the base text, but untrained readers will not find clear demarcations between the base text and the additions made to it" (p. 130). Knoppers then goes on to indicate the Chronicles to be an alternative to the primary biblical history, namely Genesis through Kings. "In this context, there is something to be said for viewing Chronicles as a second national epic. Chronicles was composed not necessarily as a replacement of, but as an alternative to the primary history" (p. 133).

The commentary part starts with an excursus on genealogies. After having explained different important aspects involved in reading biblical genealogies in general, but those in Chronicles in particular, Knoppers reacts to the question as to the literary effect of prefacing narratives about the monarchy in Chronicles with lineages of Israel's various tribes? He maintains: "In one sense, the genealogies in Chronicles are both an introduction to the people of Israel - their origins, identity, relationships - and a prologue to the story of their monarchical development in the land. ... But in another sense, the Israel discussed in the genealogies outlives the monarchy discussed in the history. ...In the context of the Persian age, those who call themselves Israelites may find themselves scattered in different lands, but even so, Jerusalem and Yehud are indispensable to their identity and future hopes as a people. In this respect, the genealogical prologue ... and the story of the monarchy..., despite their different genres, reveal similar points of view. Both end with exile..., charge the deportation to infidelity..., and announce a return..." (pp. 264-265).

The commentary in both these volumes is organized in the following way: Firstly, the translation of the specific section is repeated, together with a section with textual notes. 
After that follows a section with notes on the content of the text, as well as discussions on sources, selection, genre, composition and structure. Each section concludes with a a "comment".

A vast and very valuable bibliography on Chronicles is included on pp. 139-241 (in Vol. 12), and a few useful maps follow at the end of the first volume (Vol. 12) as well as on pp. 967-974 of the second volume (Vol. 12A). The second volume concludes with four indices: an index of biblical and ancient text references respectively, as well as an index of modern authors and a very detailed index of subjects.

These two volumes by Gary Knoppers represent cutting-edge scholarship on Chronicles and can be recommended strongly. The scholarly community can look forward to his publication of the forthcoming volume(s) on 2 Chronicles. 